\title{
EXECUTIVE DOCTORATE IN BUSINESS AT USF?
}

\author{
It looks like the demand is there...but can we pull off the rest of it?
}

Moez Limayem, the new dean of the College of Business (COB) at the University of South Florida (USF), grappled with this question as he mulled over the results of a survey that he had conducted of alumni of the school's Executive MBA program. The purpose of the survey had been to poll the group on the possibility of introducing an Executive Doctorate in Business (EDB), leading to a practice-focused terminal degree - such as a Doctor of Business Administration (DBA) - that would focus on advanced problem solving skills as opposed to the research-focused $\mathrm{PhD}$ degree already offered by the college. Not only had the email survey gotten an amazingly high response rate (around 30\%), nearly half of all the respondents had expressed interest in enrolling in the program (46 out of 97, with another 27 expressing "possible" interest). This appeared to confirm reports that he had received from other institutions that had recently introduced such programs, which were still relatively unusual in the U.S. Demand alone was not a sufficient condition for a successful program, however. A variety of other issues needed to be addressed. Among these:

- Financial viability: USF was a state supported institution but, in recent years, state support had been steadily declining as a percentage of revenue. As a practical matter, to gain approval to offer such a program the program would need to generate revenue over costs rapidly - at the moment, there was little institutional enthusiasm for programs that would add to costs overall. This might be difficult if the survey respondents' views on what the program should cost were accurate.

- Program Design: Executive doctorates tended to have objectives and organization that was very different from traditional research doctorates. Could faculty members - nearly all of whom were graduates of traditional programs - be convinced to rethink the content they covered and their approach to presenting/delivering the subject-matter in doctoral level courses to make it more appropriate to executives? Even more broadly, what topics were appropriate for executives?

- Assignment Issues: If successful, such a program would necessarily add considerable workload to a business faculty already seriously constrained in size by budgetary cutbacks. Even assuming that participation was voluntary (for additional compensation), it would likely impact the time available for research. It would be possible to contract outside faculty members to teach some courses; however, that would raise issues as well.

\footnotetext{
This case was prepared for the purpose of class discussion, and not to illustrate the effective or ineffective handling of an administrative or classroom situation and is copyrighted by the Informing Science Institute. Permission to make digital or paper copy of part or all of these works for personal or classroom use is granted without fee provided that the copies are not made or distributed for profit or commercial advantage AND that copies 1) bear this notice in full and 2) give the full citation on the first page. It is permissible to abstract these works so long as credit is given. To copy in all other cases or to republish or to post on a server or to redistribute to lists requires specific permission and payment of a fee. Contact Publisher@InformingScience.org to request redistribution permission.
}

- Objections Regarding Rigor: From preliminary discussions, it was already clear that some faculty members would likely object to such a program on principle - questioning if the degree would be sufficiently rigorous to justify awarding a doctorate. How could he address these objections? 


\section{Doctoral Programs in Business}

Compared with other academic fields of study, business has a relatively short history. Prior to the early 1900s, relatively few business schools existed (with University of Pennsylvania's Wharton School of Finance and Dartmouth University's Tuck School being the two earliest) and the MBA degree, introduced by Harvard Business School, was barely a century old. Even these early programs at prestigious institutions were viewed as being far less rigorous than their liberal arts counterparts - such as economics. Their research was, for the most part, considered anecdotal and "lightweight", a stinging criticism in the mind of many academics. There was some justification for these characterizations. In point of fact, most faculty members did not hold terminal degrees and, to the extent they did, these degrees were often in fields that were at best peripherally related to business.

In the late 1950 s, the situation came to a head after the publication of two widely circulated reports (supported by the Ford and Carnegie foundations) that offered stinging criticisms of business education and research. Largely in reaction to these criticisms, and with foundation support, in the 1960s academic business research and education began a transformation that continued for several decades. Large numbers of business doctoral candidates were trained in new theoretical and empirical research methods emerging from statistics, economics, and social sciences (such as psychology and sociology). Institutions raised their standards for research and publication. In the process, business scholars gained greater respect across the broader academic community.

\section{Traditional Business Doctoral Programs in the U.S.}

The "traditional" business doctorate, as it evolved over the past 50 years, led to a Doctor of Philosophy (PhD.) degree. The degree was modeled after doctoral degrees in other fields which, in turn, were built around the notion of a research university-first imported into the U.S. from Germany by Johns Hopkins University in 1876-in which the creation of generalizable knowledge was central to the institution's mission. In the U.S., the most respected of the business doctoral programs typically shared a number of characteristics:

- Their focus was strictly on developing academic researchers, rather than more knowledgeable practitioners. The generation of rigorous theory was generally prized above all other academic accomplishments.

- Academic standards for enrollment tended to be very high; much higher than for master's level programs such as the MBA. On the other hand, the degree to which experience in practice was prized was probably equivalent.

- They involved a period of classroom instruction followed by more independent research activities. Typically, students were required to attend these programs full-time; while occasional exceptions might be made, they were discouraged because attrition rates for such students were high—often much greater than $50 \%$.

- Most students attended on full scholarship, covering all course expenses with a modest living stipend. The most common exception to this practice was for international students - of whom there were many, and whose percentage continued to grow. This group was often subsidized by their host country.

- The emphasis of instruction was on research. Discussion seminars were the preferred structure of the courses, which tended to be focused on two distinct themes:

1. Research methods, including empirical (based on data gathering and experimentation), theoretical (heavily driven by both evidence and logical reasoning), and mathematical approaches.

2. Research findings related to the field or function being studied.

- Many, although not all, programs involved three key milestones:

1. A comprehensive exam, taken near the end of classroom instruction, that determined if the student had absorbed the necessary knowledge of methods and disciplinary research. Once 
the comprehensive exam was passed, the doctoral student was referred to as a doctoral candidate.

2. A proposal defense, where the doctoral candidate presented and justified the particular focus of the research that was to be conducted as the final stage of his or her candidacy.

3. A thesis defense, where the candidate presented the findings of his or her research to the doctoral committee that had been formed to review his or her candidacy. The traditional thesis was a book-length document intended to serve as the basis for subsequent publications in journals. In recent years, alternative structures - such as a collection of 2 or 3 journal submissions/publications - have been allowed to substitute for the thesis.

- A strong mentorship bond between faculty members and doctoral students was formed, with the frequent collaborations in their research activities. This proved beneficial to both parties since joint publications, from a career perspective, were typically given the same weight as sole-authored publications.

In their reliance on coursework for the first part of the doctorate, U.S. programs differed from many European programs, where little or no coursework was required. This difference was narrowing, however. Based on a set of agreements known as the Bologna Accords, many European Union nations were moving towards a U.S. model of higher education.

As a result of their focus, business $\mathrm{PhD}$ programs in the U.S. were seen strictly as a pathway to an academic career. While some graduates did go into other occupations, such as management consulting, most programs viewed such career decisions with disappointment. This was another manner in which U.S. attitudes differed from those in certain other countries. Germany, in particular, had a large number of doctorates in its executive ranks - as high as $80 \%$ of large company CEOs by some estimates. Most of these individuals, however, held doctorates in non-management disciplines, such as engineering.

\section{Other PhD. Programs in Business}

Over the past two decades, a growing number of U.S. business PhD's were graduated from programs falling outside of the traditional U.S. academic model. These doctorates tended to come from universities differing from those offering traditional programs in a number of ways:

- They were not accredited by the principal agency that accredits business schools, AACSB International. To the extent that they had accreditation — and most were accredited — it came from regional or online accrediting agencies.

- They enrolled mainly part-time students.

- They often included a large online component in their course offerings.

- They had relatively modest enrollment standards.

- They had much larger enrollments than traditional $\mathrm{PhD}$ programs, often in the hundreds.

- Stipends were rare, and students, therefore, covered program expenses through a mixture of personal savings and loans.

As a consequence of the first five of these characteristics, academic institutions (particularly research universities) tended to be highly suspicious of the graduates of these programs and normally rejected them out of hand for tenure-earning positions. A few graduates were hired by institutions that focused primarily on teaching. Some of the program graduates acquired their degrees while teaching at community colleges. For the most part, however, the participants in these programs did so with the goal of self-improvement or burnishing their professional credentials, rather than as a career pre-requisite. 


\section{Executive Doctoral Programs in Business}

In recent years, a number of U.S. institutions began to offer a new type of program that fit neither the traditional nor the "other" category: the Executive Doctorate in Business (EDB). Although the specific degree awarded varied from institution to institution, with Doctor of Business Administration (DBA) being the most common, they shared a number of features that distinguished them from the two other types of U.S. business doctorates. Broadly speaking, they followed an organization more typical of a professional doctorate (see Exhibit 1). In addition, the EDB programs tended to exhibit a number of specific characteristics, including:

- Very high admissions standards that weighed both past academic performance and professional accomplishment nearly equally. Work experience requirements were frequently 10 years or more.

- They were designed as part-time programs, intended for working executives, offered in blended (a mixture of face-to-face and online) fashion to provide flexibility in light of their students' busy schedules.

- Students proceeded through the program in a cohort, intended to maximize interaction among students as well as graduation rates (which seemingly were very high when compared with either the traditional or "other" programs).

- They were increasingly being offered by AACSB-accredited institutions.

- They offered few stipends.

Since there was no "certification" process in business (as opposed to other professional fields, such as medicine and education), student demand for these programs appeared to stem mainly from their desire for personal development.

In the U.S., the first program using the EDB model was the Doctor of Management (DM) degree offered by Case Western Reserve University (CWRU), in Cleveland Ohio. The details of the program are summarized in Exhibit 2. In an interview with the Case writer, Dr. Richard Boland - the program's directormade a number of comments about the CWRU program. He was particularly impressed by the program's students:

What they do is amazing... In 3 years working 20-30 hours per week, they accomplish far more than the typical doctoral student who spends at least 4 years in a full time program. With their unique access to data and their executive perspective, the resulting quality of their research is unbelievable. The biggest challenge these students present is one of establishing the proper objectives. They want to immediately try to solve problems; we need to get them to recognize that the research process requires first focusing on understanding the problems.

He also mentioned several other items that were of interest to Limayem. The first was that a great many of the graduates - as high as 50 percent — end up establishing relationships with academic institutions, either as full time faculty members or as adjuncts. While Boland thought this percentage might have started to decline in recent years, it still indicated that the executive doctorate-to-academic career pathway might be a viable alternative for some exceptional candidates. Indeed, CWRU had recently introduced a Ph.D. option, involving a fourth year in the program, which could be particularly attractive to individuals interested in a research career. All students entered into the DM program and took the same courses for their first two years. At the end of the second year, they could elect to apply to the $\mathrm{PhD}$ program, and more than half of the students had done so in recent years.

Boland also indicated that, fairly recently, the program had increased its tuition and that the result had been - if anything - an upsurge in demand. CWRU's most recent admitted cohort had, at 29 students, been its largest and yet it has also been, in many respects, the most impressive in terms of student backgrounds. Finding the best students did not seem to be the problem. Finding the right faculty, on the other 
hand, could be quite a challenge. He noted that the faculty members who attempt to mentor these students as they would their traditional doctoral students typically found the experience very frustrating. A partnership relationship was much more likely to work... and such relationships were very time consuming. He did add, however, that the program had used a number of faculty members outside of the business school with positive results. He commented that these had included an M.D., a law professor, and faculty from political science and anthropology. Limayem wondered if this might be something that USF could also try.

During the period from 2010-2012, three new programs were initiated by AACSB-accredited institutions: Georgia State University (GSU) in Atlanta, Kennesaw State University (KSU), also in the Atlanta area, and Oklahoma State University (OSU). The GSU program was seen to be a particularly good model for a potential USF program because (1) it was a state university in a large metropolitan area, (2) USF viewed GSU as a peer-level institution, and (3) it opened at the same time as KSU's program, which provided a practical indicator of the depth of enrollment demand. The details of the program are included in Exhibit 2. Dr. Lars Mathiassen, the Academic Director of the GSU program, was quick to point the distinctiveness of the executive students. With an average age of 46 and with $50 \%$ travelling from out-of-state to attend the program's residential sessions, they were very different from the "typical" GSU graduate student. The program also demanded a great deal of individual work, as opposed to the teamwork frequently emphasized at the master's level. That presented a particular problem in highly quantitative subjects, such as statistics, where executives often came in under-prepared. Like Boland, he felt that there was little chance that lack of qualified students would be a serious problem in the foreseeable future. To the contrary, he felt that existing programs could benefit from the visibility and better understanding of the degree that would come from more high quality programs being launched. Towards this end, he had been instrumental in establishing the Executive DBA Council (EDBAC), a group through which existing programs could share their experiences and where degree programs in the planning stage could go to learn more about launching such programs.

Mathiassen was unequivocal in his assertion that the biggest challenge for a new program was finding the right faculty. He opined that of about 200 faculty in GSU's business school, perhaps only 30-40 were a good fit with the program - meaning that they were research-active and were comfortable dealing with executives. Of this group, there were many who simply chose not to participate, perhaps preferring to work with the more malleable students from the school's traditional doctoral programs. In fact, two entire departments - finance and management — had (thus far) chosen to minimize their involvement in the executive doctoral program. He conceded that part of the problem was the huge amount of time that working with these students generally entailed. Unlike other graduate programs, there were no textbooks or well-established "canned" solutions that were a good fit with the executives. To be effective, each faculty member needed to devise his or her own original curriculum (and needed to be prepared to defend it when challenged by the students).

In February 2013, the first executive doctorate in business degree in the state of Florida was announced, enrolling its first cohort in fall 2013. The source of the program was somewhat unexpected: Rollins College. Principally known as a highly respected private liberal arts undergraduate institution - frequently topping the U.S. News and World Report's ratings in the southern regional university category-Rollins had never before offered a doctoral program. In fact, its AACSB-accredited Crummer Graduate School of Business was its principal foray into graduate education. With respect to the school's graduate business programs, its Executive MBA had always been highly regarded - but also quite expensive for a part-time MBA (at \$51,000 in 2003). From this perspective, extending its programs to an EDB seemed a logical next step, however - as the school's first doctoral program - doing so would require re-accreditation by the Southern Association of Colleges and Schools (SACS). On its website, the program announced that it expected to receive re-accreditation at the association's upcoming meeting, in June 2013.

Two aspects of the Rollins program immediately jumped out at Limayem (see Exhibit 2). The first was its low price tag - at $\$ 68,000$ it was less than half the cost of the CWRU program and was the cheapest of 
the AACSB-accredited executive doctorates. Given that the program had also announced that it planned to limit its cohort size to 10 candidates, it seemed that the program would, at best, break even during its first few years. His other observation involved the curriculum itself. Whereas the CWRU and GSU programs featured course titles and descriptions that suggested a highly integrative content, much of the Rollins curriculum appeared to be made up of course titles that could be readily constructed by taking a traditional MBA program's courses and preceding each of them with "Theory \& Contemporary Thought in..." Limayem thought ruefully that, from a faculty assignment standpoint, such a curriculum would be 'a dream come true'- since it would require little or no cooperation between faculty members in different departments. But would such an approach really meet the objectives of the top-level executives that he hoped to attract through offering an EDB program?

\section{Institutional Context: USF and the College of Business}

The institutional context of both the university and the college itself played an important role in determining the viability of the EDB proposal.

\section{University of South Florida}

Over its short lifetime, the University of South Florida, located in Tampa, had experienced a rise in stature matched by few other institutions in the world. Founded in 1956, by 2013 the university had transformed itself into a system soon to consist of three separately accredited institutions (the Tampa/Main campus, USF St. Petersburg, and USF Sarasota/Manatee) that covered most of the west-central region of the state. It was the eighth largest public university in the U.S. and was among 108 institutions classified by Carnegie as research university/very high (RU/VH).

\section{Goals and challenges}

Spurred by the university's past successes, for the past several years the president and provost of USF had set their sights on a new goal: achieving membership in the Association of American Universities (AAU), an organization founded in 1900 that limited itself to the top-tier of public and private universities in North America. Unlike accreditation, AAU membership did not offer any tangible benefits from a funding or eligibility for loans/grants standpoint. What it would accomplish, however, would be to cement USF's position among the top three institutions in the state (the much older University of Florida and Florida State University were the other two) and serve as an attraction in recruiting desirable students and faculty members.

According to the USF provost, the school had already achieved many of the benchmarks normally met by AAU members - particularly those involving funded research. Three areas where USF was falling particularly short were:

- Student success as measured by 6-year graduation rates. Typical for universities that had experienced rapid growth, many students were first-in-family-to-attend-college and also worked. As a result, the ratio was substantially lower for USF than for most AAU schools.

- The faculty to student ratio at 1:27, was nearly twice that of many AAU members. USF had long been hampered by a shortage of funds with which to hire sufficient faculty members to bring it to parity with the better funded AAU members. Here, part of the problem was the unusually low tuition rates set by the State of Florida. As a result of budget pressure and a reorganization of the state university system, it appeared that some flexibility to raise tuition in the future might become available.

- $\quad$ The graduate to undergraduate ratio was far lower than would be typical for an AAU university. Currently, the university had $23 \%$ graduate enrollment overall. USF would have preferred a graduate to undergraduate ratio closer to 1:3. 
USF was actively trying to remedy these deficiencies in a variety of ways. Part of the challenge faced by the College of Business was contributing to this effort.

\section{Budget situation}

As shown in Exhibit 3, in 2012-2013 the USF System had a budget with revenue totaling about \$1.7 billion. Direct state support (General Revenue) accounted for just over $12 \%$ of the total, a percentage that had been cut by almost two-thirds during the previous decade. Tuition and Fees accounted for $12 \%$ of the total, a percentage that had been growing to make up for the loss of state revenue. Student Financial Aid, used to pay tuition and other expenses, such as room \& board, represented another important source. This category included state and federal sources, such as Florida's Bright Futures program, which provided full or partial scholarships for academically strong undergraduate students from Florida high schools, Pell Grants and Stafford Loans. Contracts \& Grants, mainly a consequence of funded research, accounted for more revenue than either state support or tuition, and nearly as much as the two combined. The extraordinary expansion of USF in the research category was a major point of pride for the institution.

Facing severe budget constraints, the university was generally suspicious of introducing new programs and, particularly, new degrees. Ph.D programs, being especially costly (when stipends and small class sizes were considered), were viewed with particular suspicion. In 2011, however, the university had initiated a program that allowed for approvals of a small number of "market rate" programs each year. These programs, which required special approval, were allowed to charge whatever the market would bear and faculty members were compensated on "overload," meaning that they received extra pay for teaching the course on top of their regularly assigned duties. The College of Business already had two master's level courses approved under this program.

\section{New programs}

Regardless of whether they were market rate or regular programs, any new academic programs had to go through a series of approvals before they could be offered. The most significant of these facing the EDB, presented in order, were:

- College-level approval: The program proposal needed to be approved by college committees (e.g., Executive Committee and Doctoral Program Committee) and a vote of the faculty, before it could be forwarded by the dean to Graduate Council.

- University Graduate Council: The Council, constituted by the faculty senate, examined programs to ensure academic appropriateness and that overlap/duplication across colleges was minimized.

- Provost: The Chief Academic Officer of the university, the provost needed to approve all new programs added to the university's workplan.

- Academics and Campus Environment Workgroup of the Board of Trustees: Once the program was added to the workplan by the provost it would go through an external review process and another review by the Graduate Council before arriving at the Board of Trustees workgroup where it would be reviewed.

- Board of Trustees: Consisting of representatives of the community, approval by the BOT was the final approval required before the program could be moved to the state.

- Board of Governors (BOG): The governing body for the Florida State University System (SUS), the BOG would be responsible for final approval of a new doctoral program.

All told, the process of introducing a new program could, in theory, be completed in 2-3 years. In practice, 4-5 years was closer to the norm unless the proposal was carefully prepared and compelling in its arguments. 


\section{USF College of Business}

With around 6,000 students, USF's College of Business (COB) was second in size only to USF's College of Arts \& Sciences. In addition to its SACS regional accreditation (shared with the university as a whole), its business and accounting programs were accredited by AACSB International. The college reported approximately 105 faculty/staff (full time equivalent) and a $\$ 15$ million operating budget.

The largest programs in the $\mathrm{COB}$ were its undergraduate programs in business and accounting, with total enrollment of approximately 5,000. At the graduate level the college boasted a wide range of programs, including doctoral degrees, disciplinary master's degree programs, an MBA program and an Executive MBA program.

In attempting to support the university's goal of achieving AAU membership, the College faced a number of obstacles. These included the following:

- For the most part, business research appeared in publications that were not counted in the national research survey that determined research productivity. Similarly, business schools as a whole were not likely to acquire significant contract and grant revenue. Both research productivity and contracts and grants revenue related to the university's research goals, and were extraordinarily important to the institution's financial situation (as per Exhibit 3).

- The College's faculty-to-student ratio was far below what would be normal for an AAU business school.

- The College's graduate-to-undergraduate enrollment percentage was far below the university's as a whole. For example, according to the university's "Fast Facts" brochure, the 2012-2013 percentage was just around $14 \%$, a number that had held relatively constant for several years.

A particular area of challenge for the College related to its $\mathrm{PhD}$. programs, described as follows on the College's website:

Doctoral programs at the USF College of Business are specifically designed for scholars who aspire to become research faculty at top-tier institutions worldwide. Transforming young scholars into world-class researchers, this rigorous $\mathrm{PhD}$ program provides students with broad training in the latest research methodology as well as experience in the business classroom.

The USF College of Business is committed to providing scholars with the coursework and handson inquiry to enable their research and discovery to be published in high-quality academic journals. The College provides a level of training that will bring students to the forefront of their chosen area of study. Candidates are mentored as they complete independent inquiry and enjoy numerous opportunities to work side-by-side with respected research faculty in collaborative research programs.

Placement assistance is provided as graduates begin their academic careers at leading research institutions.

$\mathrm{PhD}$ concentrations are offered in the areas of accounting, finance, marketing, and information systems.

In many respects, these programs were exemplary—offering rigorous training to students and experiencing student attrition rates that were far lower than some of its peer competitors. The faculty members teaching in the programs were also internationally renowned-at least two of USF's departments had faculty research or program rankings in the top 50 (out of more than 4,000 higher education institutions in the U.S.). Unfortunately, its placement record at "top-tier institutions" was far below what the quality of its programs would imply. 


\section{Moez Limayem}

After an extensive search, Dr. Moez Limayem-former Associate Dean at the Sam Walton College of Business at the University of Arkansas - joined the USF College of Business as dean in July 2012. His arrival was eagerly awaited by faculty members, who looked forward to his enthusiastic style, fundraising acumen, international experience, and innovative outlook. A brief biography is included in Exhibit 4 .

Upon arriving at the college, he announced that he would be making no major changes until he had spoken one-on-one with each of the full-time faculty members. True to his word, he had scheduled nearly 100 meetings (up to an hour each) over a two month period. At each meeting, his central question had been the following: What are your ideas for making the USF College of Business better?

At one of these meetings, he was surprised to hear Grandon Gill, professor in the Information Systems \& Decision Sciences (IS\&DS) department, proposing an idea that Limayem himself had been aggressively pursuing prior to leaving his previous position: launching an executive doctorate. Perhaps even more surprising, Gill had published research on the subject in the International Journal of Doctoral Studies and had been quoted as an expert on the subject in a Bloomberg BusinessWeek article published in 2010. Limayem was immediately taken with the idea and asked the professor to prepare a brief concept summary document (included as Exhibit 5), which arrived a few days later.

Limayem realized that he would need to engage all his stakeholders if he was going to successfully move the project forward. Nothing in a university ever succeeds against the will of faculty. The administration's reaction was also important, since the university was in a state of fiscal retrenchment rather than growth; he would need to present a compelling argument for its economics. Interestingly, for this particular project two of the key stakeholders - the students and the leaders of the business community - might well be one and the same. Finally, there was the State of Florida to consider. It had indicated it would not approve duplicate programs within the state system. While no such program was presently being offered elsewhere within the state university system, Limayem doubted that this situation would remain true for long.

\section{Evolution of the EDB Program Concept}

As the end of his "listening phase" approached, Limayem decided to form an informal "Special Projects" committee to look into the EDB as well as a number of other innovative ideas that had been proposed to him. The committee, consisting of himself, the Associate Dean, the Marketing department chair and a senior faculty member (Gill, the original proposer) refined the original concept in a number of ways, recognizing that some of the assumptions, such as the notion that the program would immediately start drawing from pools such as Stanford/HBS graduates, might be a trifle optimistic. Nevertheless, the overall idea behind the program seemed sound. After a month of discussion within the special projects groupduring which the steps in the 2-3 year process of getting new program approval were determined-the decision was made to take another step: present the concept to the chairs of the College's five academic departments.

\section{Initial Presentation}

The initial presentation to the department chairs occurred at a meeting late in the fall of 2012. Generally, their reaction was positive since it seemed very likely that the program would spin off resources that could be used by other College activities and because it seemed likely to build strong and enduring relationships with executives in the local business community. There were some concerns expressed, however. The two most serious related to the following:

1. Would the program have an adverse impact on existing (traditional) doctoral programs offered by the College? As previously noted, the existing doctoral programs had experienced significant graduate placement issues. One chair was worried that the program would distract faculty attention from existing students. He also expressed concerns of what might happen to the College's reputation if another institution ended up hiring an EDB graduate - based upon a stellar record in 
business practice - only to discover that the graduate's training in academic research methods was inadequate.

2. Where would the program find the faculty to teach? The program needed to be established as a "market rate" program. As previously noted, market rate meant that tuition would be set based upon competitive programs and faculty would be paid on overload. That meant that professors would need to volunteer to teach in the program. This could lead to two possible problems. If a professor taught too many courses this way, it could not help but impact his or her productivity in other areas. Along the same lines, if too many faculty members wanted to teach in the program, it could lead to competition and perhaps a loss of morale. On the other hand, if not enough faculty members wanted to teach in the program, the situation could become even worse-arms would have to be twisted or outside faculty hired to teach specific courses (a common practice in some other programs). Having dissatisfied faculty teaching in a program like this would lead to disgruntled students - and an early demise of the entire program.

Gill had also warned Limayem that it was critical that the instructors in the program tailor their material to the needs of the audience. Faculty members who believed that doctoral level instruction could not be rigorous without advanced mathematical treatments and highly abstract theory could well find themselves at odds with the objectives of the program and the expectations of the student cohorts.

As a result of initial discussions with the chairs, Limayem felt he could begin widening the set of stakeholders to whom he presented the concept. His next group of stakeholders to consider was potential students.

\section{EMBA Alumni Survey}

At a Special Projects Committee meeting, it was jointly agreed that alumni of the school's very successful EMBA program were an obvious community for a pilot test of reaction to the concept. They had numerous characteristics in their favor:

- By virtue of having completed an MBA and having extensive work experience, they would be candidates for the program.

- They had experience with a demanding part-time program tailored to executives.

- As alumni of USF, many of their email addresses were on file and — as a bonus - many would not immediately consign emails from the program to the spam folder.

The survey was designed and pilot tested on the committee. The final list of questions is presented in Exhibit 6 . The survey was first sent out in late January 2013, with a follow-up reminder sent in midFebruary 2013. Of an estimated 300 to 400 valid email addresses, 97 responses were returned-a response rate somewhere around 30\%, which was high for email surveys. In addition, the interest level expressed was far higher than initially anticipated. Specifically:

1. 46 expressed interest in attending the program (47\%).

2. Another 27 indicated "maybe" (28\%).

3. 48 provided contact information for follow-up emails.

Participants also provided many insights into areas of interest and on program design. Many of the insights seemed to confirm past research on such programs, such as the overarching importance of personal intellectual development (see Question 4). The full results of the survey are presented in Exhibit 7. 


\section{Current Progress}

So far, indications in favor of launching the program had weighed heavily on the positive side. There was, however, no shortage of issues remaining to be resolved. One aspect of the alumni survey that was slightly concerning was the results relating to the desired price for the program. Eighty-eight percent of the responses fell in the $\$ 15,000$ to $\$ 25,000$ /year price range. With the exception of the cheaper Rollins program, this was far less than was charged for existing EDB programs, which tended to have a total three year price of around $\$ 100,000$ (the number used for the projections in the concept paper). If potential applicants really expected such a low price tag, then the high percentage of alumni expressing interest was misleading and that student demand for the program at a higher price might be substantially lower. There were two arguments against this interpretation:

1. The survey was specifically designed to not give respondents an anchor price upon which to base their estimates (e.g., it did not specify the typical price of existing programs). It was very likely that their responses were not highly fixed and would have changed given additional information.

2. The EMBA alumni group actually represented a tiny fraction of the potential set of students, which consisted of virtually the entire community of senior business executives, not only in Tampa but across the state and even the Southeast. The experience of existing programs was that a substantial number of students commuted, often from considerable distance.

Another aspect of the survey that required some thought was the breakdown of academic interests. All the programs surveyed were cohort-based and offered few-if any-electives during the coursework period of the program. For MBA programs, typically seen as being focused on "general business", this was not a problem. Doctoral programs, on the other hand, were usually much more specialized in focus. As shown by Question 5 of Exhibit 7, less than half of all respondents showed direct interest in three disciplines: accounting, finance, and MIS. General management, on the other hand, garnered high levels of interest, as did the interdisciplinary areas of business analytics, competitive analysis, and complex problem solving. What this suggested was the need for a highly interdisciplinary program. From personal experience, Limayem knew how hard it could be to get faculty members - used to working in disciplinary silos - to collaborate in this manner. Given that the program's in-state competitor, Rollins, had already introduced a program built around courses largely divided by business function, there seemed to be value in creating a curriculum organized around a different philosophy.

Delivering the program would also require some adaptability on the part of the faculty. There seemed no doubt that the program would require a substantial distance learning component (see Question 6). The faculty as a whole did not have a great deal of experience delivering programs online, however. Implementing new course designs covering interdisciplinary subject matter and relying heavily on unfamiliar delivery methods would present a serious challenge.

There was also the matter of overall program design. The question here was the degree to which it made sense to imitate other successful programs. Certain aspects of these other programs seemed so consistent that is appeared to make little sense to depart from them significantly. Among these were:

- Cohort-based structure

- High managerial experience requirements (at least 10 years)

- Duration of roughly 3 years

- Total cost in the $\$ 100,000$ range

- Roughly half to two-thirds of the program coursework based; the remainder built around guided individual research projects

- Flexibility with respect to the nature of the qualifying project or dissertation 
Despite these established program parameters, much remained to be determined. Specifically, the stated mission of the program, the specific nature of the coursework to be included, the evaluation criteria needed to ensure learning and, most important, concrete learning goals were all largely undecided. Limayem stated his overarching goal for the program as follows:

I want to see a curriculum that honors our brand and is clearly differentiated from other programs, one that provides significant value to its student and the faculty participants.

Consultation with faculty members would be the most critical element of achieving this objective. At the same time, however, Limayem was not eager to present such a design challenge to the group without some specific suggestions. Whatever opposition to the program existed would be strengthened by a proposal considered to be "half-baked."

On the other hand, he did not feel that there was a lot of time to waste in moving forward. The sudden appearance of the Rollins program had been a wake-up call. Should another state university propose an executive doctorate program, the challenge of getting the program approved by the Florida Board of Governors would increase by an order of magnitude. All the universities in the state were facing similar financial pressures, and were eager to increase their national and international visibility. USF was unlikely to be alone in following through on this opportunity. 


\section{Exhibit 1: Comparing Traditional and Professional Doctorates ${ }^{1}$}

\begin{tabular}{|c|c|c|c|}
\hline Attribute & \multicolumn{2}{|l|}{ Academic PhD } & Professional Doctorate \\
\hline $\begin{array}{l}\text { Domain of research } \\
\text { topic }\end{array}$ & \multicolumn{2}{|l|}{ Disciplinary theory } & Professional practice \\
\hline Research type & \multicolumn{2}{|c|}{$\begin{array}{l}\text { 'original investigation undertaken } \\
\text { to gain new knowledge and } \\
\text { understanding but not necessarily } \\
\text { directed towards any practical aim } \\
\text { or application' (p. } 71 \text { ) }\end{array}$} & $\begin{array}{l}\text { Issues of real interest to the } \\
\text { profession }\end{array}$ \\
\hline Research focus & \multicolumn{2}{|c|}{ A perceived gap in the literature } & $\begin{array}{l}\text { A problem encountered in } \\
\text { practice }\end{array}$ \\
\hline Starting point & \multicolumn{2}{|l|}{$\begin{array}{l}\text { Finding what is known in the } \\
\text { literature }\end{array}$} & $\begin{array}{l}\text { A problem for which the } \\
\text { solution is unknown }\end{array}$ \\
\hline $\begin{array}{l}\text { Intended learning } \\
\text { outcomes }\end{array}$ & \multicolumn{2}{|l|}{ Contribution to the literature } & $\begin{array}{l}\text { 'A significant original } \\
\text { contribution to knowledge of } \\
\text { practice }\end{array}$ \\
\hline $\begin{array}{l}\text { Integration of } \\
\text { practice/theory }\end{array}$ & \multicolumn{2}{|l|}{ Low } & High \\
\hline Research outcomes & \multicolumn{2}{|l|}{ Long dissertation } & $\begin{array}{l}\text { Shorter dissertation, often } \\
\text { more than one; project reports }\end{array}$ \\
\hline Breadth & \multicolumn{2}{|l|}{ Narrowly focused } & $\begin{array}{l}\text { More broadly focused, } \\
\text { problem-driven }\end{array}$ \\
\hline Attribute & Academic PhD & & Professional Doctorate \\
\hline Career focus & Entry into academia & \multicolumn{2}{|c|}{$\begin{array}{l}\text { Address the career needs of aspiring } \\
\text { professionals }\end{array}$} \\
\hline $\begin{array}{l}\text { Entry qualification \& } \\
\text { degree }\end{array}$ & $\begin{array}{l}\text { Undergraduate degree with } \\
\text { high marks }\end{array}$ & \multicolumn{2}{|c|}{ A Master's degree is often required } \\
\hline \begin{tabular}{|l|}
$\begin{array}{l}\text { Experience } \\
\text { requirement }\end{array}$ \\
\end{tabular} & None & \multicolumn{2}{|c|}{$\begin{array}{l}\text { 1-5 years usually expected, with a } \\
\text { median of } 3\end{array}$} \\
\hline Taught component & $\begin{array}{l}\text { Minimal, under the } \\
\text { "traditional PhD model" }\end{array}$ & \multicolumn{2}{|c|}{$\begin{array}{l}\text { Ranges from } 15 \text { to } 50 \% \text { of degree } \\
\text { requirement }\end{array}$} \\
\hline Modularity & $\begin{array}{l}\text { Relatively unstructured } \\
\text { according to the "traditional } \\
\text { PhD" model }\end{array}$ & \multicolumn{2}{|c|}{ Modular course and credit structure } \\
\hline $\begin{array}{l}\text { In-service vs. Pre- } \\
\text { service }\end{array}$ & $\begin{array}{l}\text { Pre-service for research } \\
\text { career }\end{array}$ & \multicolumn{2}{|c|}{$\begin{array}{l}\text { In-service for professional career, } \\
\text { often taken while working }\end{array}$} \\
\hline Mode of study & Full-time & \multicolumn{2}{|c|}{ Part-time } \\
\hline \begin{tabular}{|} 
Integration of \\
work/study
\end{tabular} & N/A & \multicolumn{2}{|l|}{ High } \\
\hline Cohorts & No & \multicolumn{2}{|l|}{ Yes } \\
\hline $\begin{array}{c}\begin{array}{c}\text { Variability of } \\
\text { duration }\end{array} \\
\end{array}$ & Very high & \multicolumn{2}{|c|}{ Low } \\
\hline Assessment & Dissertation driven & \multicolumn{2}{|c|}{ Separately assessed components } \\
\hline
\end{tabular}

${ }^{1}$ Source: USF College of Business Department Chairs Meeting presentation, Fall 2012. 


\section{Exhibit 2: Example EDB Programs at AACSB-Accredited Institutions}

\section{Case Western Reserve University: Doctor of Management ${ }^{2}$}

Stated Mission: "The purpose of the DM program is to develop thought leaders for the advancement of business and society."

Duration: 3 years, with an optional fourth year to complete a Designing Sustainable Systems track

Total Program Cost: $\$ 150,000$

Residency: Typically four 2 to 4-day onsite residencies per semester, plus two 2-day "virtual" residencies Admissions Requirements: Graduate degree, 15 years work experience

\section{Curriculum:}

\begin{tabular}{|c|c|c|c|}
\hline Year & Fall & Spring & Summer \\
\hline 1 & $\begin{array}{ll}\text { - } & \text { Conflict and Cooperation in } \\
\text { the Global Arena } \\
\text { - Leading Change } \\
\text { - Introduction to Research } \\
\text { Methods }\end{array}$ & $\begin{array}{l}\text { - Systems Thinking and Complex Systems } \\
\text { - } \quad \text { Structured Qualitative Research Methods I } \\
\text { - } \quad \text { Deliverables: ॰A Conceptual Paper (CP) } \\
\text { which includes the student's research } \\
\text { proposal is due in the second semester of } \\
\text { Year One. }\end{array}$ & $\begin{array}{l}\text { 2-day workshop } \\
\text { on Qualitative } \\
\text { Research } \\
\text { Methods }\end{array}$ \\
\hline 2 & $\begin{array}{ll}\text { - } & \text { Structured Qualitative } \\
\text { Research Methods II } \\
\text { - } & \text { Model Building and } \\
\text { Validation I } \\
\text { - } \\
\text { Business as a Dynamic } \\
\text { System } \\
\text { Deliverable: Qualitative } \\
\text { Research Paper }\end{array}$ & $\begin{array}{l}\text { - Leadership, Sustainability and the Global } \\
\text { Agenda } \\
\text { - } \quad \text {-Model Building and Validation II } \\
\text { - } \quad \text { Foundations of Quantitative Research }\end{array}$ & 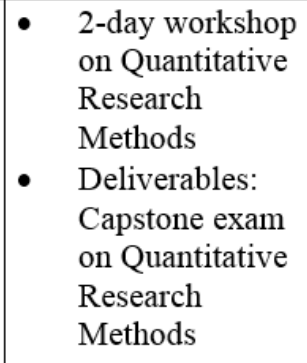 \\
\hline 3 & $\begin{array}{ll}\text { - } & \text { Technology and Social } \\
\text { System Design } \\
\text { - } \\
\text { Critical Mixed Method } \\
\text { Research Issues } \\
\text { - Advanced Analytical } \\
\text { Methods } \\
\text { - Deliverable: Quantitative } \\
\text { Research Paper }\end{array}$ & $\begin{array}{ll}\text { - } & \text { Research Dissemination } \\
\text { - } & \text { Designing Sustainable Systems Project } \\
& \text { Theories of Organizing }\end{array}$ & \\
\hline
\end{tabular}

\section{Specified Deliverables:}

The DM dissertation is a DM degree requirement. It consists of the student's Qualitative research paper (QP), the student's quantitative research paper (QNTP), and the student's integrative paper (IP) which organizes the research into a coherent whole.

${ }^{2}$ Source: All information was acquired from CWRU website 


\section{Georgia State University: Executive Doctorate in Business ${ }^{3}$}

Stated Mission: "The Executive Doctorate in Business is a three-year doctoral degree that seeks to create an active, relevant link between education and the practice of business."

Duration: 3 years

Total Program Cost: $\$ 103,000$

Residency: Typically four 3-day onsite residencies per semester; no summer sessions scheduled Admissions Requirements: Graduate degree, 10 years work experience (7 in managerial role)

\section{Curriculum:}

\begin{tabular}{|c|c|c|c|}
\hline Year & Fall & Spring & Summer \\
\hline 1 & $\begin{array}{l}\text { - Leadership to Create Human Value } \\
\text { Philosophy and Practice of Science } \\
\text { and Research } \\
\text { - Designing Qualitative Research } \\
\text { Studies }\end{array}$ & $\begin{array}{l}\text { - } \\
\text { - } \quad \text { Designining Quantitative Research Studies } \\
\text { - Lab for business driven research }\end{array}$ & N/A \\
\hline 2 & $\begin{array}{l}\text { Theory and Practice of Collective } \\
\text { Action } \\
\text { - } \quad \text { Quantitative Research Methods } 2 \\
\text { Lab for business driven research }\end{array}$ & $\begin{array}{l}\text { Emerging Markets and Global Models for } \\
\text { Business and Culture and World Politics } \\
\text { - } \quad \text { Global Economic Systems and Issues } \\
\text { - Dissertation lab }\end{array}$ & N/A \\
\hline 3 & $\begin{array}{l}\text { - Influences and Limitations on } \\
\text { Executive Decision Making } \\
\text { - Dissertation lab (x2) }\end{array}$ & $\begin{array}{ll}\text { - } & \text { Ethical Issues Confronting Contemporary } \\
\text { Business Leaders and the Role of Business } \\
\text { in Social Policy } \\
\text { - Institutional Research \& Knowledge } \\
\text { Dissemination } \\
\text { - Dissertation lab }\end{array}$ & N/A \\
\hline
\end{tabular}

\section{Specified Deliverables:}

In terms of content expectations for the dissertation, students will develop a proposal to investigate crossfunctional business problems that are of strategic importance to their firms. The students will be required to apply relevant interdisciplinary theories to inform their investigation and to apply a suitable mix of quantitative and qualitative methods for their research design, data collection and analysis. Based on their research, each student is expected to make a significant contribution to the understanding of practice at the senior management level.

The student will prepare a written proposal for the dissertation, which will be evaluated in terms of significance of problem being investigated, suitability of theories being applied, research design and data analysis. Based on the research conducted and feedback obtained during the research process, the student will prepare the final dissertation and submit it for review. In addition, the student will present the dissertation in an oral defense. To complete the requirements of the Executive Doctorate in Business, the student must pass the oral defense and obtain approval of the final written dissertation.

\footnotetext{
${ }^{3}$ Source: All information was acquired from GSU website
} 


\section{Rollins College: Executive Doctorate in Business Administration ${ }^{4}$}

Stated Mission: "An Executive Doctorate in Business Administration (EDBA) is a doctoral degree for executives who want a pragmatic and relevant program of study and will work full time while completing their degree. Many EDBA candidates pursue the degree to advance their careers, enhance their skills and knowledge, and to fulfill personal learning goals."

Duration: 3 years

Total Program Cost: $\$ 68,000$ (not including books and supplies)

Residency: Typically one 2-day (Friday/Saturday) onsite residency each month

Admissions Requirements: MBA or relevant graduate degree, 10 years work experience

\section{Curriculum:}

\begin{tabular}{|c|c|c|c|}
\hline Year & Fall & Spring & Summer \\
\hline 1 & $\begin{array}{l}\text { - Theory \& Contemporary Thought } \\
\text { in Economics } \\
\text { - Theory \& Contemporary Thought } \\
\text { in Leadership } \\
\text { - Introduction to the Philosophy of } \\
\text { Science } \\
\text { - Introduction to Research Methods } \\
\text { for Managers }\end{array}$ & $\begin{array}{l}\text { - Theory \& Contemporary Thought } \\
\text { in Finance } \\
\text { - Theory \& Contemporary Thought } \\
\text { in Marketing } \\
\text { - Introduction to Quantitative } \\
\text { Methods } \\
\text { - Introduction to Qualitative } \\
\text { Methods }\end{array}$ & $\begin{array}{l}\text { - Applied Research } \\
\quad \text { (Part 1)** }\end{array}$ \\
\hline 2 & $\begin{array}{l}\text { - Theory \& Contemporary Thought } \\
\text { in Global Business } \\
\text { - Theory \& Contemporary Thought } \\
\text { in Organizational Behavior and } \\
\text { Human Resources } \\
\text { - Approved Elective Course* }\end{array}$ & $\begin{array}{l}\text { - Theory \& Contemporary Thought } \\
\text { in Operations Management } \\
\text { - Theory \& Contemporary Thought } \\
\text { in Strategy and Strategic } \\
\text { Marketing } \\
\text { - Approved Elective Course* }\end{array}$ & $\begin{array}{l}\text { - } \quad \text { Applied Research } \\
\text { (Part 2)** }\end{array}$ \\
\hline 3 & $\begin{array}{l}\text { - } \quad \text { Integrative Experience* } \\
\text { - }\end{array}$ & - Dissertation** & - Dissertation** \\
\hline Notes: & $\begin{array}{l}\text { Courses are } 1.5 \text { credits unless other } \\
* 3 \text { Credit course } \\
* * 6 \text { Credit course }\end{array}$ & & \\
\hline
\end{tabular}

\section{Specified Deliverables:}

The dissertation phase of the EDBA program provides the opportunity for each doctoral student to develop and execute a complete research project that aims to address practical problems that are relevant within the student's own workplace or interest areas. The dissertation is supervised by a committee of faculty consisting of a chair and a second member.

\footnotetext{
${ }^{4}$ Source: All information was acquired from Rollins College website
} 
Exhibit 3: USF Operating Budget (2012-2013) ${ }^{5}$

\begin{tabular}{|c|c|c|c|c|c|c|c|c|}
\hline & \multicolumn{4}{|c|}{$\begin{array}{l}\text { 2012-13 Operating Budget } \\
\text { (In Millions) }\end{array}$} & \multirow[b]{2}{*}{ (e) } & \multirow[b]{2}{*}{ (f) } & \\
\hline & (a) & (b) & (c) & (d) & & & (g) & \\
\hline & \multicolumn{4}{|c|}{ Initial Operating Budgets } & \multirow[b]{2}{*}{ 2011-12 } & \multirow{2}{*}{$\begin{array}{c}\text { Continuation } \\
\text { Budget** } \\
2012-13 \\
\end{array}$} & \multirow{2}{*}{\multicolumn{2}{|c|}{$\begin{array}{c}\text { Submitted Budget } \\
2012-13 \\
\end{array}$}} \\
\hline & 2007-08 & 2008-09 & 2009-10 & 2010-11 & & & & \\
\hline Beginning Fund Balance: & $\$ 398.8$ & $\$ 392.4$ & $\$ 312.2$ & $\$ 460.5$ & $\$ 487.9$ & & $\$ 388.9$ & \\
\hline \multicolumn{9}{|l|}{$\begin{array}{l}\text { Budgeted Revenues (All Sources*): } \\
\text { Educational \& General (E\&G) }\end{array}$} \\
\hline General Revenue & $\$ 349.5$ & $\$ 314.9$ & $\$ 269.4$ & $\$ 286.8$ & $\$ 262.3$ & $\$ 235.1$ & $\$ 212.9$ & $-18.8 \%$ \\
\hline Lottery & $\$ 26.6$ & $\$ 35.5$ & $\$ 35.2$ & $\$ 39.7$ & $\$ 43.0$ & $\$ 34.0$ & $\$ 34.7$ & $-19.3 \%$ \\
\hline Federal Stimulus & $\$ 0.0$ & $\$ 0.0$ & $\$ 23.4$ & $\$ 22.3$ & $\$ 0.0$ & $\$ 0.0$ & $\$ 0.0$ & \\
\hline Tuition (Budget Authority) & $\$ 136.3$ & $\$ 146.2$ & $\$ 170.2$ & $\$ 193.7$ & $\$ 223.4$ & $\$ 235.5$ & $\$ 234.9$ & $5.1 \%$ \\
\hline Interest & $\$ 8.1$ & $\$ 8.3$ & $\$ 4.4$ & $\$ 0.9$ & $\$ 0.5$ & $\$ 0.5$ & $\$ 0.6$ & $23.9 \%$ \\
\hline Phosphate Research TF & $\$ 3.5$ & $\$ 2.8$ & $\$ 3.1$ & $\$ 3.0$ & $\$ 3.0$ & $\$ \$ 0.0$ & $\$ 0.0$ & $-100.0 \%$ \\
\hline Total E\&G & $\$ 524.0$ & $\$ 507.7$ & $\$ 505.6$ & $\$ 546.4$ & $\$ 532.2$ & $\$ 505.2$ & $\$ 483.1$ & $-9.2 \%$ \\
\hline \$Change Over Prior Year & & (\$16.3) & $(\$ 2.1)$ & $\$ 40.8$ & $(\$ 14.2)$ & $(\$ 27.0)$ & $(\$ 49.1)$ & \\
\hline$\%$ Change Over Prior Year & & $-3.12 \%$ & $-0.41 \%$ & $8.07 \%$ & $-2.61 \%$ & $-5.08 \%$ & $-9.23 \%$ & \\
\hline Contracts \& Grants & $\$ 320.8$ & $\$ 346.3$ & $\$ 350.3$ & $\$ 383.3$ & $\$ 380.0$ & $\$ 380.0$ & $\$ 384.6$ & $1.2 \%$ \\
\hline Auxiliaries & $\$ 151.0$ & $\$ 171.4$ & $\$ 196.3$ & $\$ 169.3$ & $\$ 185.8$ & $\$ 185.0$ & $\$ 222.0$ & $19.5 \%$ \\
\hline \multicolumn{9}{|l|}{ Local Funds: } \\
\hline Student Activities & $\$ 17.3$ & $\$ 17.6$ & $\$ 18.6$ & $\$ 15.3$ & $\$ 16.8$ & $\$ 15.9$ & $\$ 19.4$ & $15.6 \%$ \\
\hline Financial Aid*** & $\$ 270.2$ & $\$ 257.9$ & $\$ 343.0$ & $\$ 403.4$ & $\$ 377.2$ & $\$ 377.2$ & $\$ 377.5$ & $0.1 \%$ \\
\hline Concessions & $\$ 0.9$ & $\$ 0.8$ & $\$ 0.7$ & $\$ 0.6$ & $\$ 0.6$ & $\$ 0.6$ & $\$ 0.6$ & $3.6 \%$ \\
\hline Athletics & $\$ 29.4$ & $\$ 28.9$ & $\$ 29.3$ & $\$ 34.9$ & $\$ 37.7$ & $\$ 37.7$ & $\$ 39.8$ & $5.6 \%$ \\
\hline Technology Fee & $\$ 0.0$ & $\$ 0.0$ & $\$ 6.6$ & $\$ 8.3$ & $\$ 9.3$ & $\$ 9.3$ & $\$ 9.1$ & $-1.8 \%$ \\
\hline Board Approved Fees & S0.0 & \$o.0 & $\$ 0.0$ & $\$ 0.0$ & $\$ 1.1$ & $\$ 1.1$ & $\$ 1.1$ & $2.7 \%$ \\
\hline Total Local Funds & $\$ 317.6$ & $\$ 305.1$ & $\$ 398.2$ & $\$ 462.4$ & $\$ 442.7$ & $\$ 441.8$ & $\$ 447.6$ & $1.1 \%$ \\
\hline Self-Insurance Trust Funds & $\$ 6.9$ & $\$ 8.1$ & $\$ 6.2$ & $\$ 6.2$ & $\$ 6.5$ & $\$ 6.5$ & $\$ 6.4$ & $-1.2 \%$ \\
\hline Faculty Practice & $\$ 201.1$ & $\$ 145.0$ & $\$ 160.4$ & $\$ 176.6$ & $\$ 185.4$ & $\$ 185.4$ & $\$ 194.6$ & $5.0 \%$ \\
\hline Total Budgeted Revenue & $\$ 1,521.5$ & $\$ 1,483.5$ & $\$ 1,617.1$ & $\$ 1,744.3$ & $\$ 1,732.6$ & $\$ 1,703.8$ & $\$ 1,738.3$ & $0.3 \%$ \\
\hline \$Change Over Prior Year & & $(\$ 38.0)$ & $\$ 133.5$ & $\$ 127.2$ & (\$11.7) & (\$28.7) & $\$ 5.7$ & \\
\hline$\%$ Change Over Prior Year & & $-2.50 \%$ & $9.00 \%$ & $7.87 \%$ & $-0.67 \%$ & $-1.66 \%$ & $0.33 \%$ & \\
\hline Budgeted Expenditures (All Sour & & & & & & & & \\
\hline Salaries \& Benefits (includes OPS) & $\$ 714.6$ & $\$ 725.7$ & $\$ 773.5$ & $\$ 812.4$ & $\$ 804.2$ & $\$ 774.6$ & $\$ 802.5$ & $-0.2 \%$ \\
\hline Expenses & $\$ 354.5$ & $\$ 397.6$ & $\$ 290.7$ & $\$ 377.0$ & $\$ 384.1$ & $\$ 378.5$ & $\$ 376.7$ & $-1.9 \%$ \\
\hline Operating $\mathrm{Ca}_{\mathrm{a}}$ & $\$ 24.9$ & $\$ 20.5$ & $\$ 15.8$ & $\$ 14.5$ & $\$ 13.7$ & $\$ 13.4$ & $\$ 16.8$ & $22.9 \%$ \\
\hline Risk Management Insurance & $\$ 4.5$ & $\$ 5.1$ & $\$ 5.1$ & $\$ 5.5$ & $\$ 5.1$ & $\$ 5.1$ & $\$ 6.5$ & $27.1 \%$ \\
\hline Financial Aid & $\$ 242.1$ & $\$ 264.3$ & $\$ 341.1$ & $\$ 410.7$ & $\$ 384.2$ & $\$ 384.2$ & $\$ 397.5$ & $3.4 \%$ \\
\hline Library Resources & $\$ 8.0$ & $\$ 6.9$ & $\$ 7.1$ & $\$ 6.9$ & $\$ 6.8$ & $\$ 6.7$ & $\$ 6.6$ & $-3.3 \%$ \\
\hline Phosphate Research Trust Fund & $\$ 7.2$ & $\$ 4.5$ & $\$ 7.3$ & $\$ 7.3$ & $\$ 4.8$ & & $\$ 0.0$ & $-100.0 \%$ \\
\hline Debt Service & $\$ 7.1$ & $\$ 7.2$ & $\$ 7.2$ & $\$ 9.3$ & $\$ 7.5$ & $\$ 7.5$ & $\$ 7.5$ & $-0.4 \%$ \\
\hline Total Operating Budgeted Expenditures & $\$ 1,363.0$ & $\$ 1,431.9$ & $\$ 1,447.8$ & $\$ 1,643.7$ & $\$ 1,610.6$ & $\$ 1,570.0$ & $\$ 1,614.0$ & $0.2 \%$ \\
\hline \$ Change Over Prior Year & & $\$ 68.9$ & $\$ 16.0$ & $\$ 195.9$ & $(\$ 333.1)$ & & $\$ 3.4$ & \\
\hline$\%$ Change Over Prior Year & & $5.05 \%$ & $1.11 \%$ & $13.53 \%$ & $-2.01 \%$ & & $0.21 \%$ & \\
\hline Non-Operating Expenses & $\$ 162.1$ & $\$ 211.2$ & $\$ 115.4$ & $\$ 144.4$ & $\$ 136.6$ & $\$ 136.6$ & $\$ 187.2$ & $37.0 \%$ \\
\hline Projected Ending Fund Balance & $\$ 395.27$ & $\$ 232.9$ & $\$ 366.0$ & $\$ 416.7$ & $\$ 473.2$ & & $\$ 326.0$ & \\
\hline$\$$ Change Over Prior Year & & $(\$ 162.4)$ & $\$ 133.2$ & $\$ 50.6$ & $\$ 56.6$ & & $(\$ 147.2)$ & \\
\hline
\end{tabular}

*All sources include the budgets that must be included in the operating budget for submission to BOG. The budget does not include DSOs except for Faculty Practice. The operating budget would not include capital construction.

**The continuation 2012-13 initial budget is requested at last year's level, excluding the budget for USF Polytechnic and the Florida Phosphate Institute. The University will prepare a 2012-13 budget for submission to the BOG by August 17th and for presentation to the Board of Trustees at the September meeting.

\footnotetext{
${ }^{5}$ Source: http://system.usf.edu/board-of-trustees/finance-and-audit/pdfs/upcomingmeetings/112912/2012130peratingBudget.pdf
} 


\section{Exhibit 4: Biography of Dean Moez Limayem}

\section{Moez Limayem, PhD}

- Dean for USF's College of Business

College of Business

University of South Florida

Phone: (3) (813) 974-4281

Fax: (813) 974-3030

Email

\section{Brief Biography}

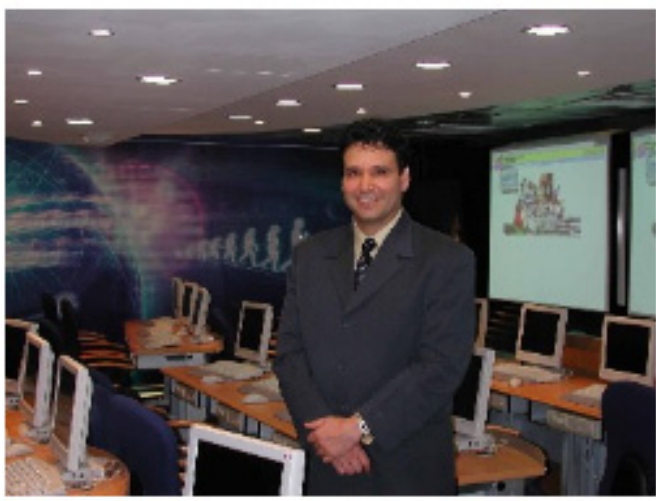

Moez Limayem is dean of the College of Business, joining USF in 2012 from the Sam M. Walton College of Business at the University of Arkansas, where he served simultaneously as the associate dean for research and graduate programs, the executive director of the Information Technology Research Institute and the Radio Frequency Identification Center, and the Edwin \& Karlee Bradberry Chair in Information Systems. Limayem was responsible for all the graduate business programs and executive education programs and also supervised 11 outreach and research centers.

The recipient of numerous professional awards, Limayem has published dozens of articles, many of which focus on the intersection of technology with the consumer, academic and business worlds. He is also the coauthor of a scholarly book, "Understanding The Use of Technology-Based Self Service: The Consumers' Point of View."

Limayem's recent research focuses on the use of mobile phones and technology in dangerous settings. He has also recently emerged as an expert on the power of social media and information systems to effect social and political change. He has been quoted in outlets ranging from the Christian Science Monitor to the Times of India.

Limayem worked in the private sector as a systems analyst and computing consultant before receiving his MBA and PhD in business administration from the University of Minnesota. Since 1992, he has served as an international expert in IT for UNESCO. He has taught at universities across the globe: he taught at the University of Minnesota, Laval University in Canada, City University of Hong Kong, and Lausanne University in Switzerland, as well as the University of Arkansas.

Source: USF Web Page 


\title{
Exhibit 5: Initial DBA Concept Document
}

\author{
Executive Business Doctorate: \\ A Proposal Summary
}

\section{Executive Summary}

There appears to be a strong and, for the most part, unmet demand for a business doctorate that can be earned by working executives. Developed as a part-time, cohort-based, market-rate program, such a degree could add to the prestige of USF, build relationships that could enable future research and make a substantial financial contribution to the College of Business and the University as a whole.

\section{The Concept}

As managers enter the executive ranks, it becomes increasingly difficult for them to differentiate themselves from their colleagues. By that point in their career, an MBA has become nearly a given. Executive non-credit programs, such as those offered by HBS, represent one possible path - they are expensive, however, and open to only a few. Another alternative is to pursue a doctoral degree. While commonplace in other countries (e.g., in Germany, an estimated 80\% of top executives have doctorates), however, such degrees are rare in the U.S. That situation is changing, however, and evidence from the relatively few doctoral programs that cater to executives suggests that they are in great demand and offer substantial financial rewards to the institutions that offer them. They also represent an opportunity to substantially increase graduate enrollment. Nova Southeastern University-presently the only institution located in Florida that offers such degrees - reportedly has several hundred professional doctoral students between its Graduate Business and Graduate Communications schools despite the fact that it is regionally, but not AACSB, accredited.

Professional Development: An Executive Business Doctorate (EBD) is likely to serve two needs: 1) the executive's personal need for professional development, and 2) a long term interest in transitioning to academia. Existing programs appear to be drawing from both needs, although they nearly always emphasize that their primary focus is professional development. Even discounting the academic pathway, however, demand for such programs appears to be strong. A program recently initiated at Georgia State University, for example, is reported to have had 100 applications for 20 available slots.

From a practitioner's standpoint, the ideal doctoral program would include a number of elements. Among these:

1. It would offer a flexible schedule that would permit the executive to continue working.

2. It would emphasize problem solving rather than theory development.

3. It would emphasize self-directed learning

4. It would be cohort-based, since working with a cohort of colleagues vastly reduces attrition rates.

5. It would provide the opportunity to work away from campus.

6. It would allow the executives own activities to become a central focus of research.

Transition to Academic Employment: Even though they strongly emphasis their goal of professional development, programs at institutions such as Case Western Reserve University (CWRU) and Robert Morris University (RMU) frequently include some students employed at universities. For these individuals, the doctorate represents a pathway to academic advancement. There is reason to believe, however, that the opportunity to use such programs as a gateway to academia may grow in the future. 
For years, AACSB has been predicting a near-catastrophic shortage of academically qualified business faculty. In 2007, for example, they predicted that retiring senior faculty members would result in at least 2,500 unfilled positions by 2012. This situation has by-and-large failed to materialize, however, although some fields have experienced shortages. In large measure, this failure can be attributed to the rapid drop in the stock market that occurred in the intervening years, dramatically reducing the retirement accounts of individual near retirement age and, in many cases, forcing them to postpone retirement.

One possible consequence of the present situation could be that when the financial markets experience the inevitable surge of performance that follows a downturn, we could see retirements occurring at a rate that is vastly higher than the distribution of ages would predict. Because of their highly labor-intensive structure, conventional academic doctoral programs will not be able to ramp up to meet such demand. Under such circumstances, executive doctoral programs - which can ramp up much more quickly - could easily become an important source of faculty. Moreover, when hiring an executive doctorate for an academic position, the professional pedigree of the executive is likely to matter at least as much as the institution granting the degree, provided that institution has the appropriate accreditation.

In addition to all the ideal characteristics of a professional-development focused doctorate, the "transition to academia" doctorate would benefit from some additional characteristics:

7. It would cover content areas where the executive's experience is likely to be very limited (e.g., how to be an effective teacher, publishing in an academic journal).

8. It would ensure that the candidate was fully acquainted with the values, culture and practices of the academic community that he or she was aspiring to join upon graduation.

To accomplish these objectives, the duration of such a track might have to be extended.

\section{The Proposal}

Goals: Establish a market-rate EBD program that can lead to two types of $\mathrm{PhD}$. degrees: a degree totally focused on professional development and a degree that includes additional content specifically related to an academic career. Each year, the 3+ year program would enroll a cohort of 15-20 executives (a typical size for such programs).

Feasibility: There are several key issues that impact the potential feasibility of such a program. From the institutional side, the only way such a program makes sense is as a market rate program. This would provide the needed flexibility in delivering, locating, pricing and adjusting the size of the program. The likelihood that the market rate option will be available in the future may vary based upon legislative priorities, past experience with such programs, and (potentially) opposition from sister state institutions.

With respect to demand, we must rely heavily on anecdotal experiences of other programs - which seem to support the feasibility strongly - and other indicators of demand. For example, with respect to the "transition to academia" track, when the HBS MBA class of 1982 was surveyed for their $25^{\text {th }}$ reunion in 2007, their responses were as follows:

- $30 \%$ (39 out of 147 responses) identified being a college/university faculty member as their ideal non-business career (by far the greatest percentage of the dozen or so options provided).

- Of these $30 \%, 4$ indicated that they were dead serious or had already made the move and 10 were toying with the idea. The remaining 25 were either dreaming about it or not really interested.

- The median net worth of the group of the 14 most serious individuals was \$5-10 million, suggesting that nearly any cost-justifiable price tag would be within reach. Assuming $4 \%$ of the class (using just under half of the 15 strong responses) as a reasonable estimate during the career span when they might consider making the transition, roughly 30 students could be serious candidates from a single 750 person HBS class. 
- Presumably, when executives from other prestigious universities (e.g., Northwestern, Virginia, possibly Stanford) were added, a pool of 100-150 plausible candidates would be generated each year. During the early years of the EBD program, however, it would be reasonable to expect to draw upon candidates from a 10 year pool of classes (e.g., age range 40 to 50), so the initial pool could be in the 1000-1500 range nationally.

Costs: To get a sense of the contribution-generating potential of the program, consider the following set up assumptions (which consider direct costs of instruction and amenities only-administration, marketing, overhead, etc. are all ignored):

- Revenue: Total 3 year program price: $\$ 100,000 /$ student

- Cost: $20 \%$ attrition (occurring midway in the program): $\$ 10,000 /$ student [lost tuition revenue]

- Cost: 3 year books and food (during residency periods): $\$ 10,000 /$ student

- Cost: 10 courses per year @ $\$ 15,000 /$ course for 2 years: $\$ 300,000$

- Cost: Dissertation supervision: $\$ 10,000 /$ student

The table that follows shows the net contribution towards overhead, marketing, administration, etc. that would be generated at different enrollment levels. These are computed on a "per cohort" basis which-if one assumes one cohort per year-will translate into a per year contribution once three cohorts are concurrently enrolled:

\begin{tabular}{|c|c|c|c|c|}
\hline $\begin{array}{l}\text { Enrollment } \\
\text { Level }\end{array}$ & Total Revenue & $\begin{array}{l}\text { Direct Variable Costs } \\
\text { (\$30,000/student * } \\
90 \% \text { effective outlay) }\end{array}$ & $\begin{array}{l}\text { Total Cost } \\
\text { (including courses@) } \\
\$ 300,000 / \text { cohort) }\end{array}$ & $\begin{array}{l}\text { Contribution } \\
\text { per Cohort }\end{array}$ \\
\hline 5 & $\$ 500,000$ & $\$ 135,000$ & $\$ 435,000$ & $\$ 65,000$ \\
\hline 10 & $\$ 1,000,000$ & $\$ 270,000$ & $\$ 570,000$ & $\$ 430,000$ \\
\hline 15 & $\$ 1,500,000$ & $\$ 405,000$ & $\$ 705,000$ & $\$ 795,000$ \\
\hline 20 & $\$ 2,000,000$ & $\$ 540,000$ & $\$ 840,000$ & $\$ 1,160,000$ \\
\hline
\end{tabular}

Presuming the program acquired enough seed capital from private sources to cover its initial marketing and administrative outlays, it is reasonable to believe that a break-even of 5 students would be achievable. More to the point, at half the targeted enrollment of 20 (likely to be the maximum for a single cohort), the program starts to begin generate substantial cash that could be used to fund activities in the sponsoring colleges. In considering whether these numbers are reasonable or not, it is worth noting the following:

1. The tuition is reasonably in line with RMU's $(\$ 100,000$ vs. $\$ 75,000$ at RMU) and a bit less than that of the Case Western Reserve University Executive Doctorate $(\$ 102,000)$. The GSU program reportedly costs $\$ 120,000$.

2. The $\$ 33,000 /$ year tuition is less than comparable tuition at any elite MBA program

3. The projected loss of $20 \%$ is twice the attrition reported by RMU

4. Substantial allowance is being made for items often not included in such calculations (e.g., paying faculty to supervise candidate dissertations and mentor students)

\section{Benefits}

Assuming that we instituted such a program, I see the benefits as including:

- Substantial contribution of resources to the USF College of Business and university as a whole.

- Increase in graduate enrollment. 
- Establishing enduring long-term relationships with high level executives

- Potential to place high level executive graduates in peer or aspirant institutions (should a shortage of business faculty materialize).

Establishing visibility through becoming the first such program offered by a state university in Florida. 


\section{Exhibit 6: EMBA Alumni Survey Questions}

1. Have you ever heard of an executive business doctorate?*

2. Have you ever met or do you know of anyone who has received an executive business doctorate?*

3. Would you have any interest in becoming more involved in designing or participating in our executive business doctorate?*

4. Assuming that you decided to enroll in an executive business doctoral (EDB) program, how much value would you attach to each of the following potential benefits?*

Improved ability to understand academic research

Improved ability to conduct academic research

Improved problem solving skills

Ability to network and interact with other EDB candidates in the cohort

Professional recognition

Personal intellectual development

Ability to teach graduate courses part time

Potential for transitioning to academia

5. What topic areas are of greatest interest to you?
Accounting
Finance
Marketing
Management
Information technology
Business analytics
Competitive analysis and strategy
Organizational and product design
Complexity and decision making
Creativity and innovation
Other, please specify

6. EDB programs typically balance required face-to-face classroom sessions (often held on weekends) and more flexible online learning options. How would you recommend that we balance these?*

Heavy emphasis on in-class sessions

Moderate emphasis on in-class sessions

In-class and distance learning roughly balanced

Moderate emphasis on online learning

Heavy emphasis on online learning

7. EDB programs tend to include three types of activities: formal course work, mentored activities (under the direction of a faculty member), group research activities (conducted with other members of the EDB cohort) and independent research activities. * 
Please rank the following (top to bottom) in terms of where we should place our emphasis?

Rank the items below, using numeric values starting with 1.

Formal course work

Mentored activities

Group research activities

Independent research activities

8. The total cost of existing EDB programs vary widely. Assuming that the program is cohort-based and takes three years to complete, please indicate which of the following seems like a fair price (per year). In answering this question, assume that higher price-tags allow the program to offer more features and opportunities.

$$
\begin{aligned}
& \$ 5,000-\$ 14,999 / \text { year } \\
& \$ 45,000-\$ 54,999 / \text { year } \\
& \$ 25,000-\$ 34,999 / \text { year } \\
& \$ 55,000 \text { or more/year } \\
& \$ 15,000-\$ 24,999 / \text { year } \\
& \$ 35,000-\$ 44,999 / \text { year }
\end{aligned}
$$

9. Assuming that you were enrolled in an EDB program, how much would the following activities interest you?
Working directly with faculty members
Attending U.S. conferences
Attending international conferences
Writing academic articles
Writing trade journal articles
Writing a book
Learning research methods
Learning business analytics
Learning teaching techniques

10. Would you like us to contact you if the EDB program moves forward?*

We will not use your contact information for any other purpose.

11. Please provide us with your email address

\section{First name or nickname}

\section{Last name}

14. Would you be willing to attend a focus group on how we might structure and market such a program?

15. In the event that we decide to go ahead with offering an Executive Business Doctorate, would you have any interest in serving on an Executive Advisory Board for the program?

16. Do you have any further comments?

Enter your comments below, in the box provided. 


\section{Exhibit 7: EMBA Alumni Survey Results}

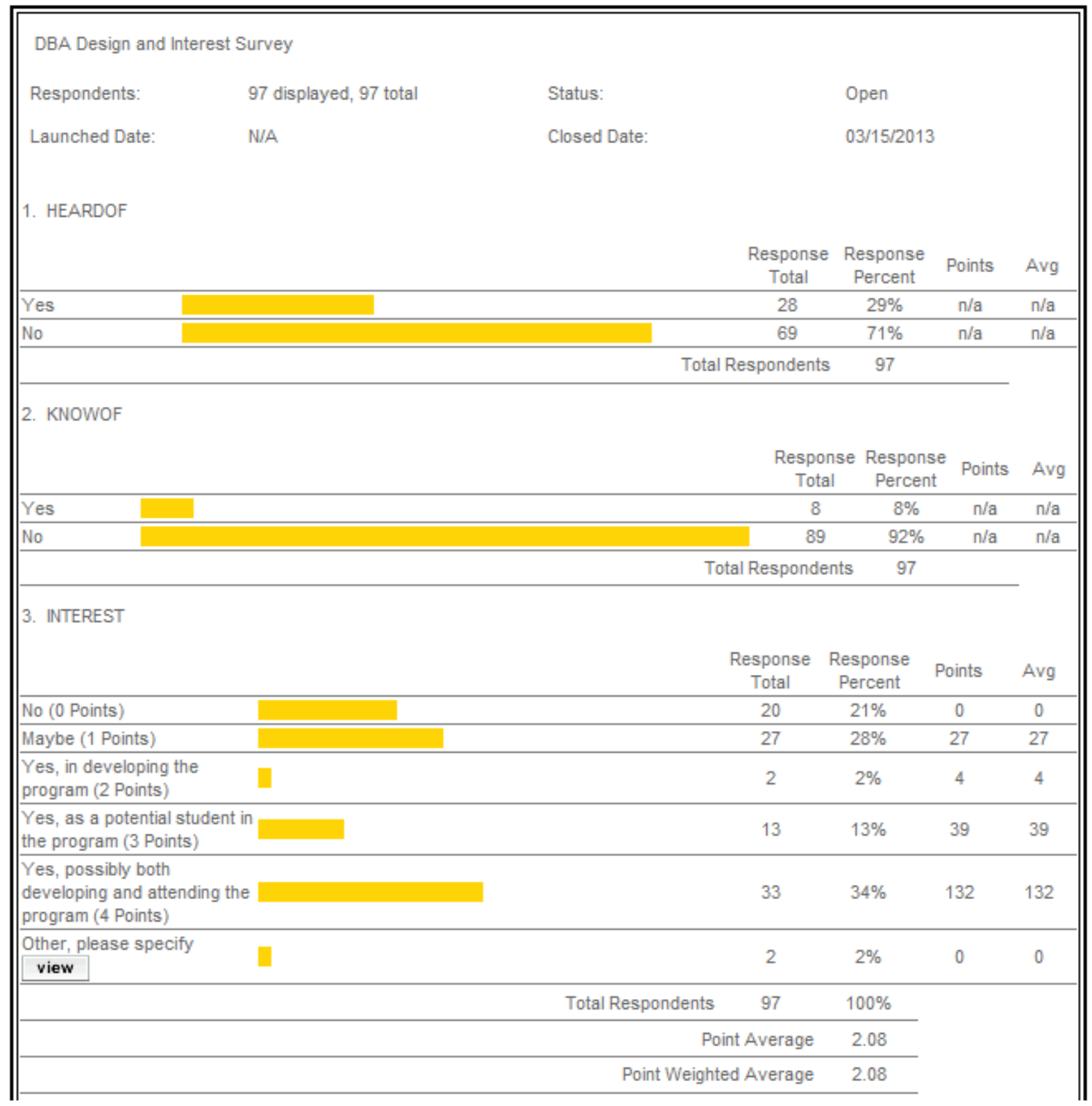




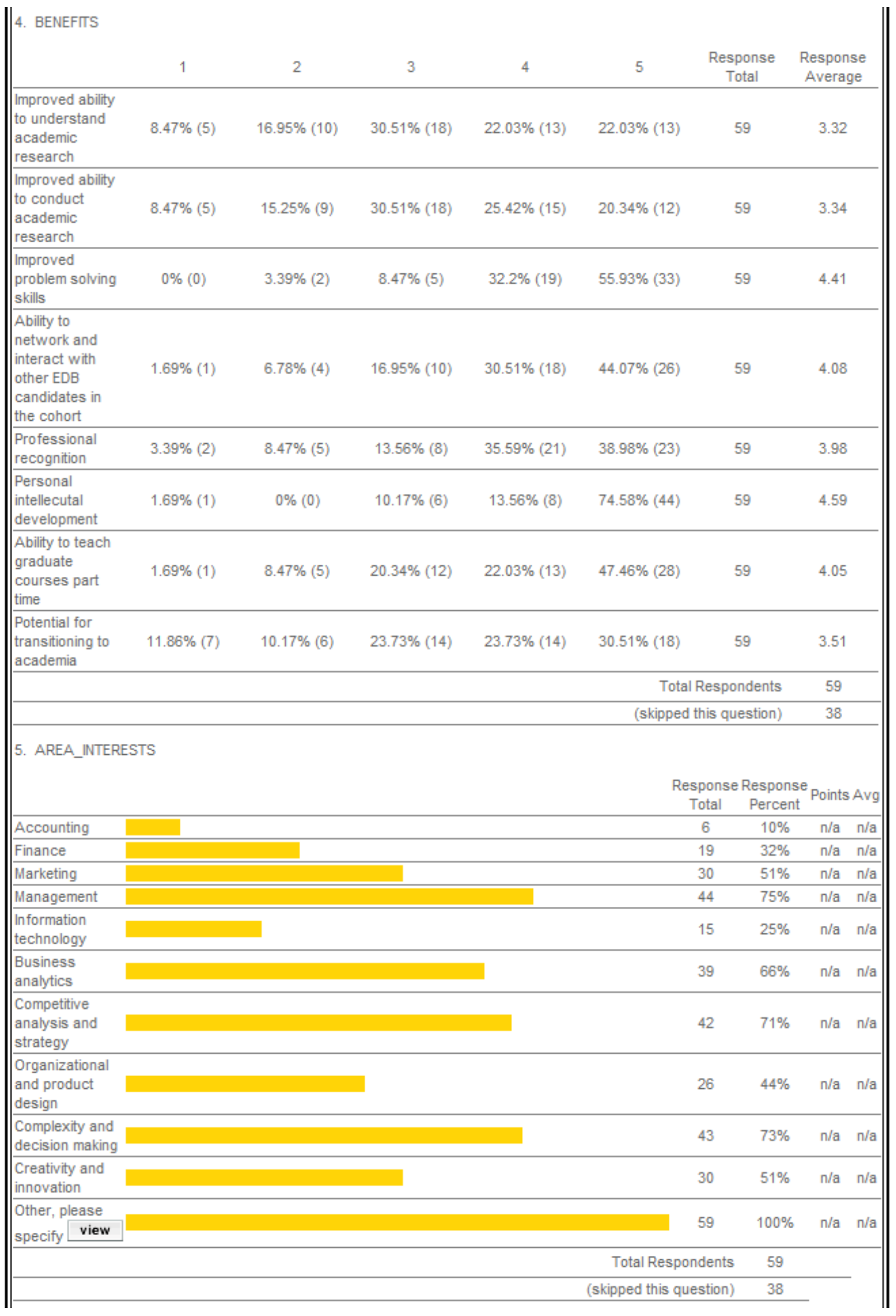




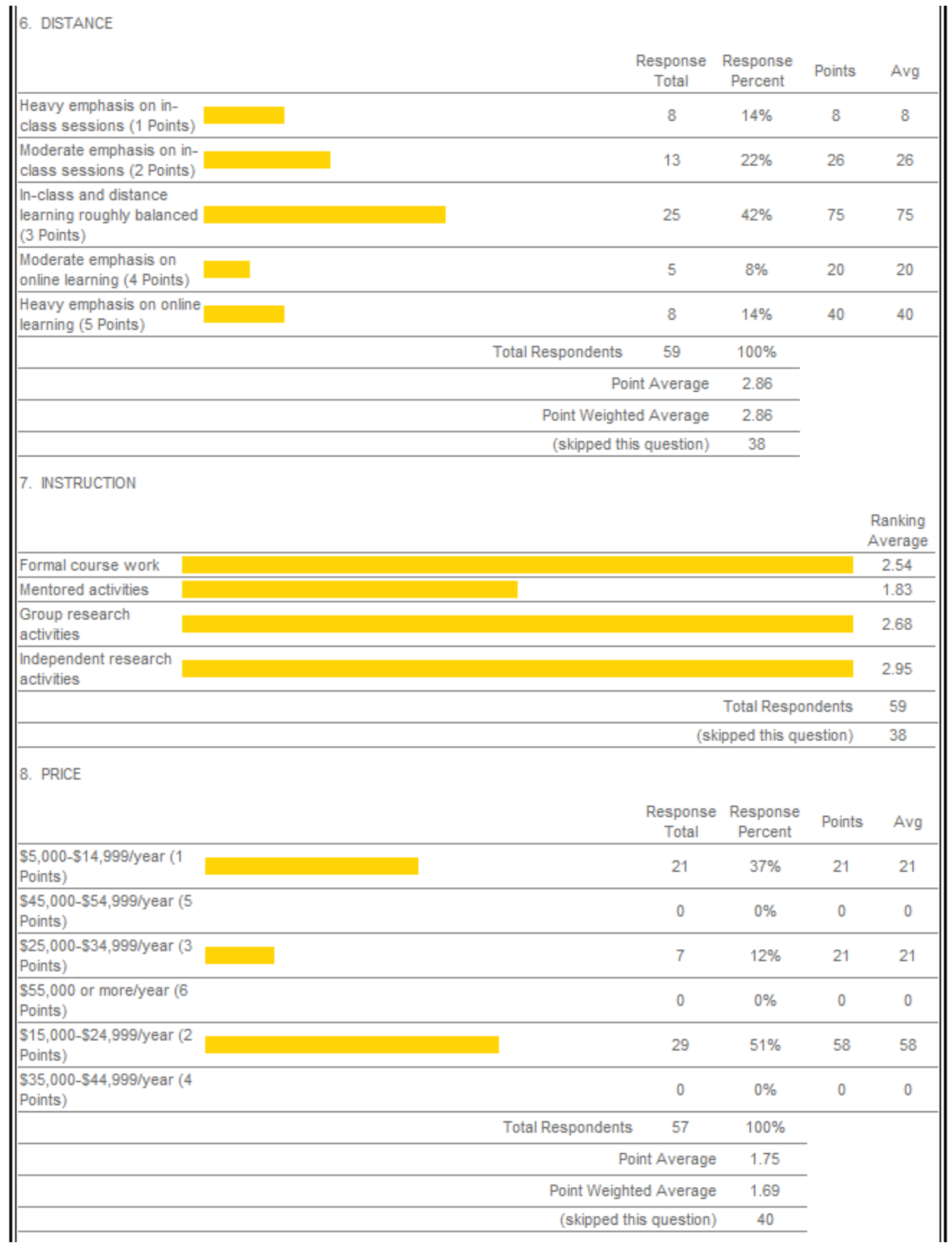




\begin{tabular}{|c|c|c|c|c|c|c|c|c|}
\hline & 1 & 2 & 3 & 4 & 5 & $\begin{array}{c}\text { Response } \\
\text { Total }\end{array}$ & \multicolumn{2}{|c|}{$\begin{array}{l}\text { e Response } \\
\text { Average }\end{array}$} \\
\hline $\begin{array}{l}\text { Working directly with faculty } \\
\text { members }\end{array}$ & $0 \%(0)$ & $5.08 \%(3)$ & $16.95 \%(10)$ & $28.81 \%(17)$ & $49.15 \%(29)$ & \multicolumn{2}{|l|}{59} & 4.22 \\
\hline Attending U.S. conferences & $1.69 \%(1)$ & $10.17 \%(6)$ & $28.81 \%(17)$ & $32.2 \%(19)$ & $27.12 \%(16)$ & \multicolumn{2}{|l|}{59} & 3.73 \\
\hline $\begin{array}{l}\text { Attending international } \\
\text { conferences }\end{array}$ & $3.39 \%(2)$ & $15.25 \%(9)$ & $20.34 \%(12)$ & $28.81 \%(17)$ & $32.2 \%(19)$ & \multicolumn{2}{|l|}{59} & 3.71 \\
\hline Writing academic articles & $1.72 \%(1)$ & $15.52 \%(9)$ & $27.59 \%(16)$ & $32.76 \%(19)$ & $22.41 \%(13)$ & \multicolumn{2}{|l|}{58} & 3.59 \\
\hline Writing trade journal articles & $1.69 \%(1)$ & $10.17 \%(6)$ & $32.2 \%(19)$ & $35.59 \%(21)$ & $20.34 \%(12)$ & 59 & \multicolumn{2}{|c|}{3.63} \\
\hline Writing a book & $10.17 \%(6)$ & $22.03 \%(13)$ & $18.64 \%(11)$ & $23.73 \%(14)$ & $25.42 \%(15)$ & 59 & \multicolumn{2}{|c|}{3.32} \\
\hline Learning research methods & $8.47 \%(5)$ & $10.17 \%(6)$ & $11.86 \%(7)$ & $35.59 \%(21)$ & $33.9 \%(20)$ & 59 & \multicolumn{2}{|c|}{3.76} \\
\hline Learning business analytics & $0 \%(0)$ & $5.08 \%(3)$ & $5.08 \%(3)$ & $38.98 \%(23)$ & $50.85 \%(30)$ & 59 & \multicolumn{2}{|c|}{4.36} \\
\hline \begin{tabular}{|l} 
Learning teaching \\
techniques
\end{tabular} & $0 \%(0)$ & $10.17 \%(6)$ & $22.03 \%(13)$ & $32.2 \%(19)$ & $35.59 \%(21)$ & 59 & & 93 \\
\hline & & & & & Total & al Responder & & 59 \\
\hline & & & & & (skipped & $\mathrm{d}$ this questic & & 38 \\
\hline 10. CONTACT & & & & & & & & \\
\hline & & & & & $\begin{array}{l}\text { Response } \\
\text { Total }\end{array}$ & $\begin{array}{c}\text { Response } \\
\text { Percent }\end{array}$ & Points & Avg \\
\hline Yes & & & & & 48 & $81 \%$ & $n / a$ & n/a \\
\hline No & & & & & 11 & $19 \%$ & $n / a$ & $n / a$ \\
\hline & & & & Total R & espondents & 59 & & \\
\hline & & & & (skipped th & is question) & 38 & & \\
\hline 11. EMAIL & & & & & & & & \\
\hline & & & & Vie & w responses & $s$ to this ques & stion $v$ & ew \\
\hline & & & & & Total Re: & espondents & 48 & \\
\hline & & & & & (skipped this & is question) & 49 & \\
\hline 12. FNAME & & & & & & & & \\
\hline & & & & Vie & W responses & $s$ to this ques & stion $v$ & ew \\
\hline & & & & & Total Re: & espondents & 48 & \\
\hline & & & & & (skipped this & is question) & 49 & \\
\hline 13. LNAME & & & & & & & & \\
\hline & & & & Vie & w responses & $s$ to this ques & stion $v$ & ew \\
\hline & & & & & Total Re & espondents & 48 & \\
\hline & & & & & (skipped this & is question) & 49 & \\
\hline 14. FOCUS & & & & & & & & \\
\hline & & & & & $\begin{array}{l}\text { Response } \\
\text { Total }\end{array}$ & $\begin{array}{c}\text { Response } \\
\text { Percent }\end{array}$ & Points & Avg \\
\hline Yes & & & & 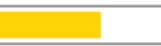 & 39 & $81 \%$ & $n / a$ & n/a \\
\hline No & & & & & 9 & $19 \%$ & $n / a$ & n/a \\
\hline & & & & Total R & espondents & 48 & & \\
\hline & & & & (skipped th & is question) & 49 & & \\
\hline $\begin{array}{l}\text { 15. In the event that we deci } \\
\text { on an Executive Advisory Bo }\end{array}$ & $\begin{array}{l}\text { le to go ahead } \\
\text { rd for the pro }\end{array}$ & $\begin{array}{l}\text { with offering a } \\
\text { ram? }\end{array}$ & Executive Bus & iness Doctorate & , would you $\mathrm{h}$ & have any int & terest in $s$ & serving \\
\hline & & & & & $\begin{array}{l}\text { Response } \\
\text { Total }\end{array}$ & $\begin{array}{c}\text { Response } \\
\text { Percent }\end{array}$ & Points & Avg \\
\hline Yes & & & & & 40 & $83 \%$ & $n / a$ & $n / a$ \\
\hline No & & & & & 8 & $17 \%$ & $n / a$ & n/a \\
\hline & & & & Total R & espondents & 48 & & \\
\hline & & & & (skipped th & is question) & 49 & & \\
\hline
\end{tabular}




\section{Comments:}

This program if it takes form could help USF take the next level in academic prestige.

Good idea. we need to keep pace with other leading EBD programs and especially other countries providing this type of education. good luck.

When I went through the EMBA program it was quite advantageous that there was a scholarship available for people dedicated to working in the nonprofit sector. I was the recipient for my class, and I think it can be shown that I added value to the cohort (I was one of only two 4.0 students in the group). Moreover, I believe it can be shown that having received the MBA has added value in my nonprofit work for the past 10 years; on the whole the scholarship was a very good investment for USF and its donor(s).

Those of us who serve in the nonprofit environment are often viewed as "lightweights" by people who work in a corporate environment. The only thing that is "lightweight" in many cases is our salary. I strongly suggest that the planning include consideration of how the doctoral cohort will be diverse in all the usual ways PLUS include people from NPOs, NGOs and perhaps government/military leaders as well.

Since it is not common in the US, how would the business community view and regard an Executive Doctorate? Would the time, effort and cost to pursue such an advanced degree be more suitable in academia or potentially be relegated to a research position in a corporation? What are the benefits and opportunities?

If I was twenty years younger I would be interested but I am not interested at 60 and President of my own Company.

This opportunity comes as a pleasant and welcome surprise. Since graduating from the EMBA program, I continue to nurture relationships with former professors and stay tuned to the progress being made.

I have dreamt about potentially teaching at the university level and as a minimum furthering my academic career beyond the MBA. I would be greatly please to contribute in any way possible. Of particular value for you might be that I have a deep and wide experience in international business and relationships. I'm currently the Principal Consultant and Designer of customer experience at NCR Corporation - so I would be able to provide outside-in and inside-out perspectives.

How many weekends/ month?

Only Saturdays or ...?

How many hours?

Will also have to focus offering Financial Assistance/Schorlarships to future students. That would sure help in the recruitign efforts for this new course.

I would be highly interested in a Program that offered stipends, teaching assistant opportunties, and on the job grants to augment the cost of the program as well. This will be crucial in attracting future Doctorate students.

I have a BSN from Illinois Wesleyan University and MA in counseling and EMBA from USF. Due to the extreme problem with enough openings at USF for prospective students in nursing due to a shortage of credentialed faculty I think more emphasis needs to be placed on advanced degrees. In nursing a d other health related fields. Cathy Johnson. Ex $\mathrm{m}$ a class of 1992 
I think this is an exciting opportunity. I had abandoned the possibility of pursuing my doctorate because I couldn't see how I could afford it and balance it with my work/social life. I now see hope again.

Great idea. Thanks for including past students. Go Bulls!

I am currently looking at a doctoral program at UF for 2014

One of my disappointments with USF after receiving my MBA was that they removed the Management focused Ph.D program.

The suggestions made above would require a similar approach in other US universities to begin to have some major impact within one decade. It may sound somewhat idealistic, but when China and India take over the world in 30 years or less this effort could be too little to late. America needs to wake up and get with the program of making US a really great example of democracy and leadership. It is starving for a new breed of leadership with integrity and respect in business and government alike - so yes we need this Doctorate program and we need to do or right. Thanks for asking my opinion. Good luck with this endeavor.

It would be far more useful to expand the MBA to include specialties such as IT, Health, HR or Product Line Development.

If one has a BA, and MBA is already feeling pretty redundant. The idea of a doctorate seems misguided in a business environment desperate for more value.

The program is exciting. I am concerned for myself however. My under graduate and eMBA are both from USF. I would hate to limit my academia future opportunities for all of my eggs in one basket.

Doctorate degrees may be more common in Europe and Australia, but I'm not convinced that an executive business doctorate would have equivalent value in the U.S. I worked for Sykes, a global outsourcing company headquartered here in Tampa. None of the Sykes EMEA employees that I worked with from the UK, Germany, the Netherlands, the Nordics or South Africa had doctorate degrees. Nor did any clients - from Sony, HP, Exxon, Deutsche Telekom, SAS or TeliaSonera - that I met from those countries. I think that, for the U.S. market, the ability to focus an executive MBA in specific disciplines such as marketing, accounting, organizational management, finance, economics or MIS would be more valuable to U.S.-based companies than an executive doctorate. The business culture simply isn't the same and I don't think U.S. companies would value a doctorate in business.

I continue to value my educational experience at and continued association with the USF College of Business. I continue to be open to being of assistance in any role where (time permitting) I can add value to either the Executive MBA or DBA programs

Not really a good fit for me at my current age. I completed my MBA in 1989. I do hope you are able to put a program together for others.

I am retired from Deloitte Consulting now, thus I would not be interested in such a program. Would have been 20 years ago.

I am very interested in being involved in whatever way I can. 